\title{
Incorporation of astrocaryum vulgare (tucuma) oil into PCL electrospun fibers
}

\author{
Nathan Rampelotto Bressa ${ }^{1}$ (D), Vinícius Rodrigues Oviedo ${ }^{2}$ (D), Aline Machado Bessow Machado ${ }^{1}$ (D), \\ Willians Lopes de Almeida ${ }^{3}$ (D), Tiago Moreno Volkmer ${ }^{4}$ (D), Luis Alberto Loureiro dos Santos ${ }^{5}$ (D), \\ Michele Rorato Sagrillo ${ }^{2}$ (i) and Luiz Fernando Rodrigues Junior ${ }^{1 *}$ (D)
}
'Departamento de Engenharia Biomédica, Universidade Franciscana - UFN, Santa Maria, RS, Brasil 2Programa de Pós-graduação em Nanociências, Universidade Franciscana - UFN, Santa Maria, RS, Brasil
3̇Instituto Federal de Educação, Ciência e Tecnologia do Amapá, Macapá, AP, Brasil ${ }^{4}$ Departamento de Engenaharia de Materiais, Universidade Federal de Pelotas - UFPel, Pelotas, $R$ S, Brasil

\section{${ }^{5}$ Laboratório de Biomateriais e Cerâmicas Avançadas - LABIOMAT, Departamento de Engenharia de Materiais, Universidade Federal do Rio Grande do SuI - UFRGS, Porto Alegre, RS, Brasil}

*luiz.fernando@ufn.edu.br

\begin{abstract}
The aim of this study was to incorporate tucuma oil (Astrocaryum vulgare) into PolyCaprolactone (PCL) electrospun fibers and evaluate its physicochemical properties and cell viability. FTIR and DRX confirmed that tucuma oil (TO) does not affect the chemical properties of PCL and that the oil was loaded into the PCL microstructure, while TGA analysis showed that the oil increased the thermal stability of the polymeric fibers. SEM showed that the addition of the oil modified fibers structure by reducing the average fiber size from $5.5 \mu \mathrm{m}$ to $1.7 \mu \mathrm{m}$ for TO loaded samples. Cell viability assay demonstrated an increment on cell proliferation from $80 \%$ of pure PCL to $100 \%$ for samples containing TO. Therefore, it can be concluded that tucuma oil can be incorporated into PCL to form fibers by electrospinning, without meaningful changes in its physicochemical properties and increasing its biocompatibility.
\end{abstract}

Keywords: cytotoxicity, vegetal oil, fibers.

How to cite: Bressa, N. R., Oviedo, V. R., Machado, A. M. B., Almeida, W. L., Volkmer, T. M., Santos, L. A. L., Sagrillo, M. R., \& Rodrigues Junior, L. F. (2021). Incorporation of astrocaryum vulgare (tucuma) oil into PCL electrospun fibers. Polímeros: Ciência e Tecnologia, 31(3), e2021036. https://doi.org/10.1590/0104-1428.20210056

\section{Introduction}

There are several studies focusing on the manufacture of polymeric fibers and one of the most used processes is electrospinning ${ }^{[1-8]}$. This technique has such as being able to produce scaffolds with a controlled fiber diameter, high surface area, and porous structure ${ }^{[1,9-12]}$. The ability to reproduce and manipulate the electrospinning process in vitro on a spatiotemporal scale similar to that of native tissue provides a great potential of clinical success ${ }^{[6,13,14]}$. The wide range of commercially available biomaterials, as well as the strategies adopted in tissue engineering and regenerative medicine, favor the search for new products and methodologies to obtain these $\mathrm{e}^{[15-17]}$.

In line with this approach, the manufacture of scaffolds from absorbable, hydrolytically degradable polymers belonging to the aliphatic polyester class is being widely investigated for the use in tissue engineering ${ }^{[18-24]}$. Their inherent biocompatibility properties and the possibility of undergoing hydrolysis in the body make these biomaterials suitable for the tissue reconstruction process. In addition to these, one can list its ease of processing and modulation of degradation rate, mechanical and visco-elastic properties ${ }^{[25]}$.

Electrospun fibers are extremely attractive in the biomaterials field due to their large surface area to volume ratio $^{[26]}$. Its potential applications include tissue engineering scaffolds, drug delivery media, wound healing, filtration media, composites ${ }^{[8,27,28]}$, among others. It is known that the properties and internal molecular structure of polymers are strongly affected by their processing conditions. Thus, understanding the processing - structure - property relationship is of great importance for the development of polymeric fibers that meet the demands of the desired application ${ }^{[29]}$.

Several studies have been seeking viable alternatives for the use of absorbable polymers containing natural oils as those oils may enhance the material properties without significantly alter the structure of the polymeric matrix. In this idea, the tucuma oil shows great application possibilities, due to the small toxicity presented and efficiency in the controlled drug delivery ${ }^{[30]}$. 
The tucuma palm (Astrocaryum vulgare), which is found in the Amazon Rain forest, is considered a pioneer of expressive growth, fire resistant with ability to sprout after burning and mainly inhabits the poultry and pastures. The kernel of the palm tree is externally covered with an oily orange canopy from which the oil is extracted ${ }^{[31]}$. Among tropical seeds, tucuma palm is an economical source of vegetal oils ${ }^{[32]}$ and it is also abundant in the northwest, north, and central-west regions of Brazil ${ }^{[33]}$. Besides that, the simplicity of the extraction process to obtain the oil, which is mainly based on mechanical cold-pressing ${ }^{[34]}$, also turns it into a promising biotechnological resource. In this view, tucuma oil has been already used in the biomedical field due to the high fatty acids content and the fact it has several carotenoids as bioactive compounds ${ }^{[35]}$. Based on the aforementioned, its incorporation into electrospun biomaterials trends to improve biocompatibility in addition to physical-chemical properties ${ }^{[36-40]}$.

In this work, a study for obtaining PCL fibers with the addition of tucuma oil by the electrospinning process was carried out. The proposal aimed to evaluate whether the tucuma could be electrospun together with the PCL and whether this product would present good biocompatibility for its application as scaffolds or dressings for pressure injuries. Different amounts of tucuma oil were added to the PCL and its impact on morphology, physical and chemical properties, and its cytotoxic effect in cell media were studied.

\section{Materials and Methods}

\subsection{Electrospinning methodology}

For the preparation of a homogeneous polymer solution, $15 \%(\mathrm{w} / \mathrm{v})$ PCL was dissolved in acetone at $50{ }^{\circ} \mathrm{C}$ using a hot plate and it was magnetic stirred until the polymer was completely solubilized. This solution was transferred to a $5 \mathrm{~mL}$ syringe with an 18 gauge needle. After some tests, the experimental parameters were optimized to $10 \mathrm{kV}$ of potential difference and $10 \mathrm{~cm}$ distance between the tip of the needle containing the polymeric solution and the target. The tucuma oil was added into polymeric PCL solution before the electrospun process on the concentrations describe in Table 1.

\subsection{Characterization}

\subsubsection{X-ray diffraction (XRD)}

The characterization of the crystalline planes of the samples was performed using a Bruker D2 PHASER diffractometer. Couple Two Theta/ Theta scan with 1482 steps of 1 second, $2 \theta$ from $5^{\circ}$ to $70^{\circ}$ and increment of $0.05^{\circ}$ per

Table 1. Parameters used in the electrospinning technique.

\begin{tabular}{cccc}
\hline Sample & $\begin{array}{c}\text { Oil } \\
\text { Concentration } \\
(\boldsymbol{\mu g} / \mathbf{m L})\end{array}$ & Distance $(\mathbf{c m})$ & $\begin{array}{c}\text { Electric } \\
\text { potential }(\mathbf{k V})\end{array}$ \\
\hline PCL & 0 & 10 & 10 \\
PCLT100 & 100 & 10 & 10 \\
PCLT250 & 250 & 10 & 10 \\
PCLT500 & 500 & 10 & 10 \\
\hline
\end{tabular}

second. The search was done at the International Center for Diffraction Data (ICDD) Database, file PDF2014 PDF-2 Release 2014 RDB.

\subsubsection{Fourier-transform infrared spectroscopy (FTIR)}

The FTIR technique was used to verify the presence of functional groups in the PCL matrix. The assay was performed on a Spectrometer FTIR/NIR, model FRONTIER, brand PERKINELMER, with ATR methodology and resolution of $8 \mathrm{~cm}^{-1}$ and scanning from 4000 to $650 \mathrm{~cm}^{-1}$.

\subsubsection{Thermogravimetric analysis (TGA)}

Thermal behavior of samples was evaluated under $\mathrm{N}_{2}$ atmosphere with flow rate of $20 \mathrm{~mL} / \mathrm{min}$ and heating rate of $10^{\circ} \mathrm{C} / \mathrm{min}$. The testing was performed from 30 to $600^{\circ} \mathrm{C}$ using one Perkin Elmer instrument, model TGA 400.

\subsubsection{Scanning electron microscopy (SEM)}

The morphology and size of the fibers were characterized by scanning electron microscopy (SEM), using a Hitachi, model tm3000 (secondary electron - SE). The software Image J was used to measure the diameter of the fibers. Fifty measurements were performed per sample

\subsubsection{Cell viability (MTT)}

The MTT assay for cell viability was used to verify the cytotoxicity of the obtained scaffolds by using an experimental protocol similar to that described by Wilms et al. ${ }^{[41]}$.

Blood Collection for toxicological tests: Peripheral blood samples were obtained from three discard samples from the Clinical Analysis Laboratory of the Franciscan University, under the approval of the Institution's Human Ethics Committee (CAAE: 31211214.4.0000.5306) with no identification data. Samples were obtained by venipuncture using Vacutainer ${ }^{\mathbb{R}}$-type heparin tubes, which were used to separate the Peripheral Blood Mononuclear Cell (PBMCs).

Treatments: A culture medium containing only the cells was used as a negative control, while the PCL, PCL100, PCL250, and PCL500 samples were incubated with PBMCs in an environment with $5 \% \mathrm{CO}_{2}$ at $37^{\circ} \mathrm{C}$ for $24 \mathrm{~h}$. Moreover, the results were represented as a function of optical density and then, the cell viability was calculated through spectrophotometry at the $570 \mathrm{~nm}$ wavelength, according to Equation 1:

$$
\text { CellViability }(\%)=\frac{O D 570 e}{O D 570 b} \times 100
$$

Where:

OD570e: mean value for optical density of $100 \%$ of the extract of the test samples.

OD570b: mean value for optical density of the blanks.

\subsection{Statistical analysis}

For the analysis of the SEM images, the IMAGE J software was used, where 50 measurements were taken from each group. Subsequently, the data were entered at the software OriginPro 8.1. The one-way ANOVA test was used to see if there was a significant difference between the measurements where $\mathrm{p}$ would have to be less than 0.05 . 
Also, for the MTT assay for cell viability, the treatments were compared to the negative control through one-way ANOVA to check for statistical differences between the groups and Dunnett's post-hoc test to compare their means. The $95 \%$ confidence interval was used and $\mathrm{p}<0.05$ were considered significant.

\section{Results and Discussions}

Figure 1 shows the diffractograms selected for PCL and the PCL mixed with tucuma oil at $250 \mu \mathrm{g} / \mathrm{mL}$ and it shows it has the same structural characteristics. When the PCL/tucuma is analyzed at different concentrations, a crystal structure is obtained ${ }^{[30]}$. Diffractogram peaks present between $2 \Theta$ ranging from $21^{\circ}$ to $24^{\circ}$ are typical of PCL.

The FTIR-ATR spectrum of tucuma oil, PCL and PCL + tucuma oil are shown in Figure 2 and it contains characteristics

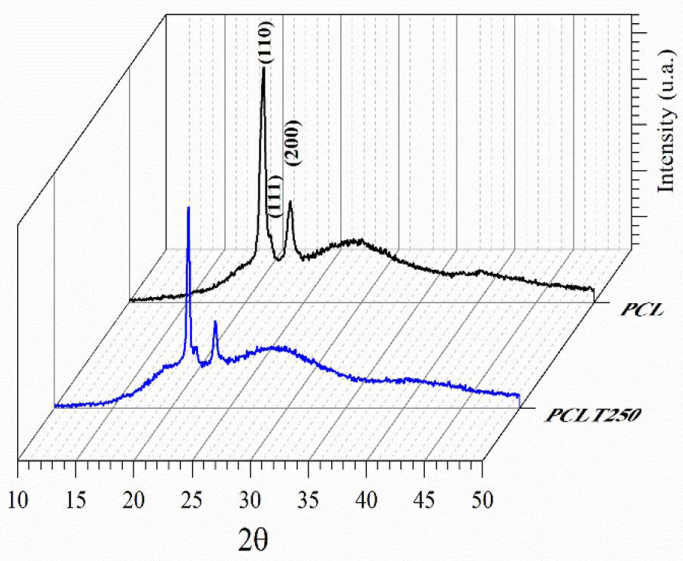

Figure 1. Diffractograms of pure PCL and PCL samples with $250 \mu \mathrm{g} / \mathrm{mL}$ of tucuma oil.

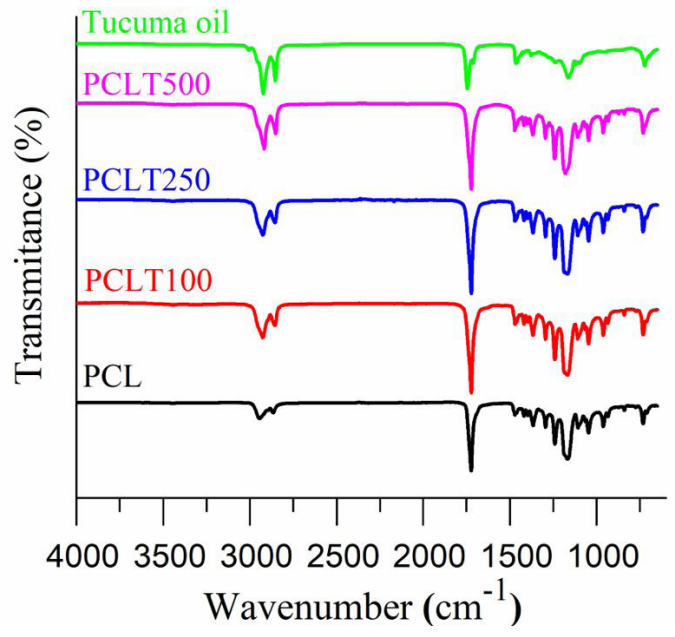

Figure 2. Infrared spectroscopy of PCL and PCL samples with $100 \mu \mathrm{g} / \mathrm{mL}, 250 \mu \mathrm{g} / \mathrm{mL}$ and $500 \mu \mathrm{g} / \mathrm{mL}$ of tucuman oil. bands of a vegetable oil ${ }^{[42-45]}$. These bands are described in Table 2, according to the findings of Leonardi et al. ${ }^{[42]}$, Ali et al. ${ }^{[44]}$ and Gomez et al. ${ }^{[45]}$. Bands in the region between 2980 and $2830 \mathrm{~cm}^{-1}$ are characteristic of the asymmetric and symmetric stretching modes of the $\mathrm{C}-\mathrm{H}$ methylene group. This molecule is present both in PCL and in vegetable oils, such as tucuma. The carbonyl $\mathrm{C}=\mathrm{O}$ aliphatic stretching was observed in $1733 \mathrm{~cm}^{-1}$ and $1744 \mathrm{~cm}^{-1}$ to $\mathrm{PCL}$ and $\mathrm{PCl}+$ tucama oil, respectively.

It was observed that the incorporation of tucuma oil in PCL resulted in an increase in the intensity of the bands related to the methylene group, since all samples of PCL + tucuma presented greater intensity in these bands when compared to pure PCL. Nevertheless, it is not possible to see a significant difference in these intensities when the PCL + tucuma oil spectra are compared between them. Thus, the FTIR results suggest that the quantity of $100 \mu \mathrm{g} / \mathrm{mL}$ is sufficient to promote alterations in PCL properties.

Figure 3 shows the SEM images from PCL and PCL with tucuma oil. The medium diameter from PCL fibers was the $5.3 \pm 3.7 \mu \mathrm{m}$ and the PCL fibers with tucuma oil were $1.72 \pm 0.90 \mu \mathrm{m}, 2.6 \pm 1.3 \mu \mathrm{m}, 2.9 \pm 1.2 \mu \mathrm{m}$, to samples with $100 \mu \mathrm{g} / \mathrm{mL}, 250 \mu \mathrm{g} / \mathrm{mL}$ and $500 \mu \mathrm{g} / \mathrm{mL}$, respectively. The ANOVA test showed a significant difference among PCL fibers diameter and all samples with tucuma oil. The same result was observed between and PCL plus $100 \mu \mathrm{g} / \mathrm{mL}$ and PCL plus $500 \mu \mathrm{g} / \mathrm{mL}(\mathrm{p}<0.05)$, despite of difference between fibers diameter from PCL plus $100 \mu \mathrm{g} / \mathrm{mL}$ and PCL plus $250 \mu \mathrm{g} / \mathrm{mL}$ the ANOVA test did not find a significant difference when comparing them $(p=0.29)$. These results were different from the work from Felgueiras et al. ${ }^{[46]}$, where there was not statistical change in fiber diameters when an essential oil was added to polymer fibers. However, them are in accord with the showed by Tampau et al. ${ }^{[47]}$ and Hasanpour Ardekani-Zadeh and Hosseini ${ }^{[48]}$, where the addition of oil furthered the diameter fibers reduction, when compared to polymer without oil. This comportment could be explained by change of physical-chemical characteristics

Table 2. ATR-FTIR spectrum analysis for all samples ${ }^{[35,37,38]}$.

\begin{tabular}{ccc}
\hline $\begin{array}{c}\text { Wave } \\
\text { number } \\
\left(\mathbf{c m}^{-1}\right)\end{array}$ & Attributed band & Reference \\
\hline 3006 & $=$ CH Stretching & Leonardi et al. ${ }^{[42]}$ \\
2922 & $\mathrm{CH}_{2}$ Assymetric stretching & Leonardi et al. ${ }^{[42]}$ \\
2853 & $\mathrm{CH}_{2}$ Symetric stretching & Leonardi et al. ${ }^{[42]}$ \\
1743 & $\mathrm{C}=\mathrm{O}$ Aliphatic strecthing & Leonardi et al. ${ }^{[42]}$ \\
1710 & $\mathrm{C}=$ O Stretching & Leonardi et al. ${ }^{[42]}$ \\
1650 & $\mathrm{C}=\mathrm{C}$ Stretching & Gomez et al. ${ }^{[45]}$ \\
1464 & $\mathrm{CH}_{2}$ scissoring deformation & Leonardi et al. ${ }^{[42]}$ \\
1417 & In-plane deformation of & Leonardi et al. ${ }^{[42]}$ \\
& C-O-H & \\
1377 & Symetric flexion of CH & Leonardi et al..$^{[42]}$ \\
1239 & C-O Stretching & Leonardi et al. ${ }^{[42]}$ \\
1161 & $\mathrm{C}-\mathrm{O}$ (esther) Stretching & Leonardi et al. ${ }^{[42]}$, \\
1117 & & Ali et al. ${ }^{[44]}$ \\
1095 & & \\
721 & $\mathrm{CH}_{2}$ Rocking deformation & Leonardi et al. ${ }^{[42]}$, \\
& & Ali et al. .44$]$ \\
\hline
\end{tabular}



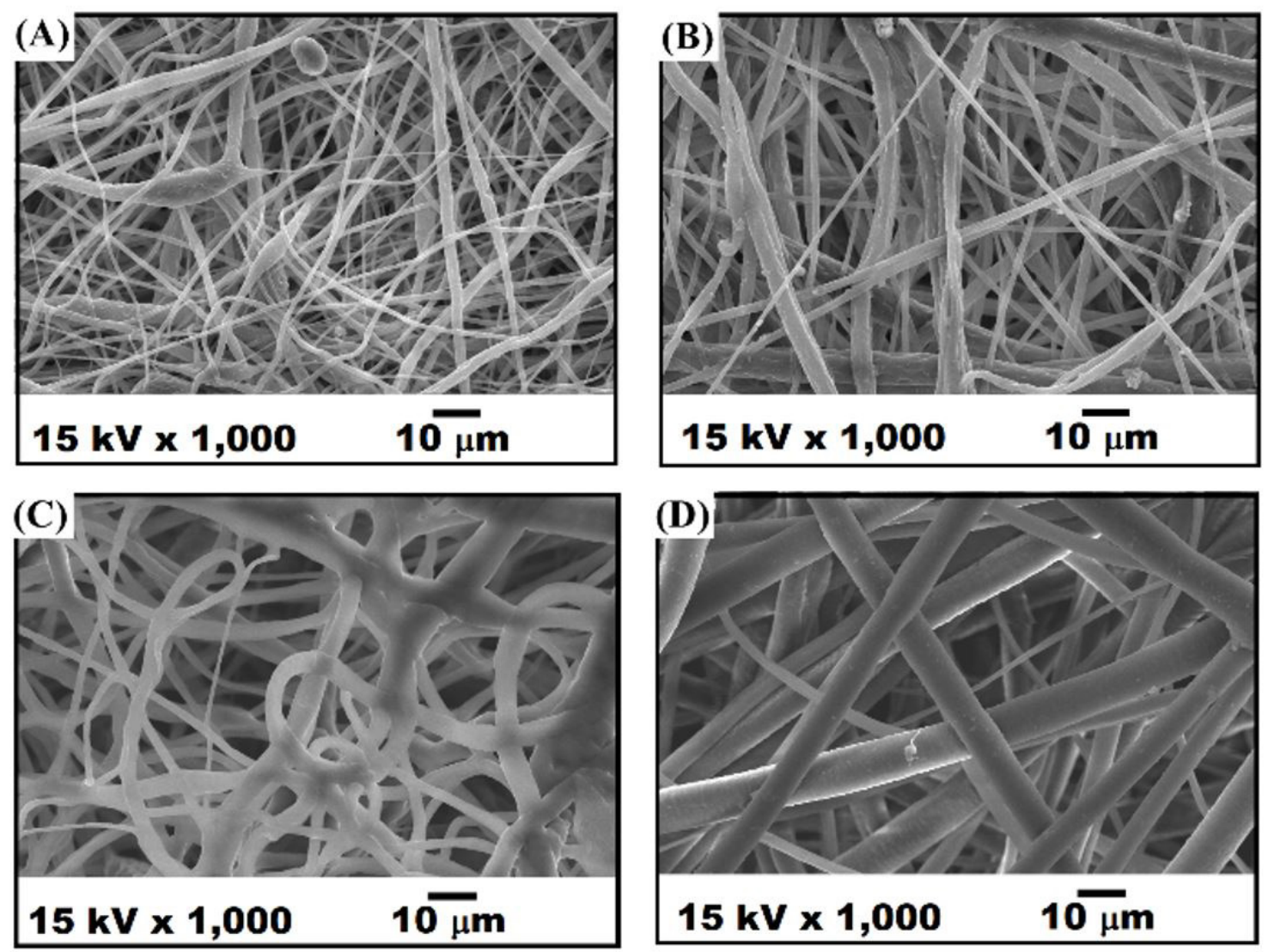

Figure 3. SEM of samples with different concentrations of oil and pure PCL, (A) $100 \mu \mathrm{g} / \mathrm{mL}$, (B) $250 \mu \mathrm{g} / \mathrm{mL}$, (C) $500 \mu \mathrm{g} / \mathrm{mL}$ and (D) PCL.

of the polymer solution by tucuma oil that modifying the chain entanglements, responsible for fiber formation ${ }^{[49]}$. Figure 4 shows the SEM image to PCL plus $500 \mu \mathrm{g} / \mathrm{mL}$ tucuma oil where can be see a region in the sample that polymeric fibers collapsed. This could be justified by the insufficient evaporation of solvent due the large quantity of tucuma oil ${ }^{[49]}$. This result could explain the increased of diameter fibers from samples loaded with more tucuma oil, where minus tucuma oil has finner fibers and great quantity of tucuma oil has thicker fibers $(1.72 \pm 0.90 \mu \mathrm{m}$ to PCL plus $100 \mu \mathrm{g} / \mathrm{mL}$ and $2.9 \pm 1.2 \mu \mathrm{m}$ to PCL plus $500 \mu \mathrm{g} / \mathrm{mL}$ ).

Thermogravimetric analysis (Figure 5) showed that the tucuma oil incorporation $(100-500 \mu \mathrm{g} / \mathrm{mL})$ in PCL leads to a higher thermal stability. Moreover, the events in the region around $330{ }^{\circ} \mathrm{C}$ in Figure 5B, Figure 5C and Figure 5D may be occurring together with another thermal event, resulting in a wide endothermic peak around $423^{\circ} \mathrm{C}$. To verify this, the DTG curve for sample PC500 (Figure 6) was analyzed by least squares fit of gaussian functions and deconvolution revealed two peaks $\left(392{ }^{\circ} \mathrm{C}\right.$ and $\left.424^{\circ} \mathrm{C}\right)$. This result is consistent with the other samples (PCL100 and PCL250), however, it is noted that the endothermic peaks were moved to higher temperatures. This is due to the greater amount of tucuma oil added to the PCL.

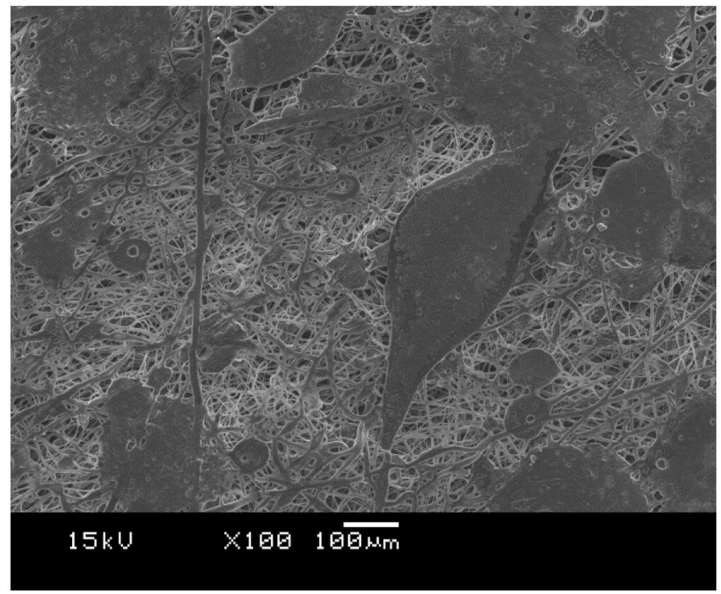

'Figure 4. SEM of PCL500 sample.

The in vitro effect of tucuma-loaded fiber scaffolds on PBMCs donated by volunteers was investigated by MTT (Figure 7). Test results showed no cytotoxicity behavior in any of the evaluated samples. Pure PCL nanofibers showed a cell viability around $95.7 \%$ against PBMC cells, however, 
(A)

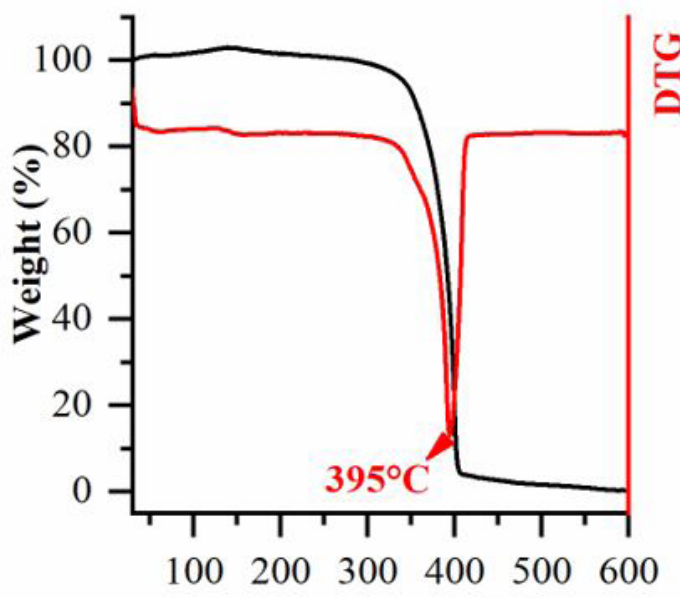

(C)

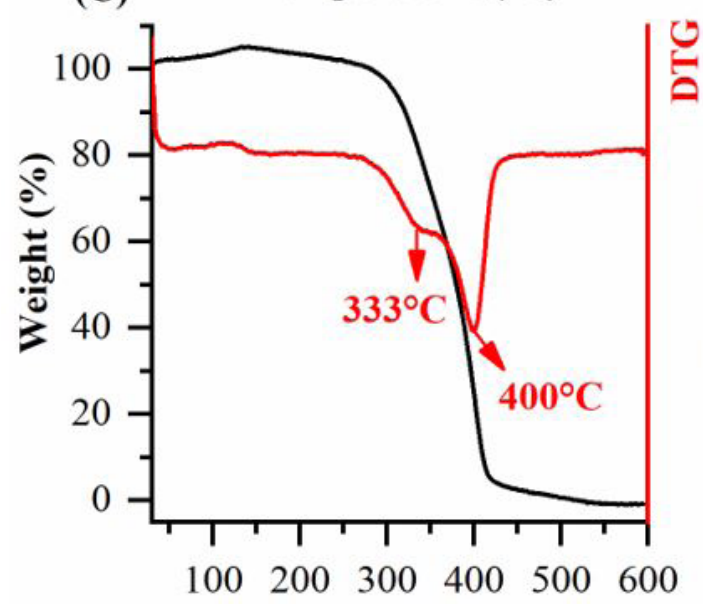

Temperature $\left({ }^{\circ} \mathrm{C}\right)$
(B)

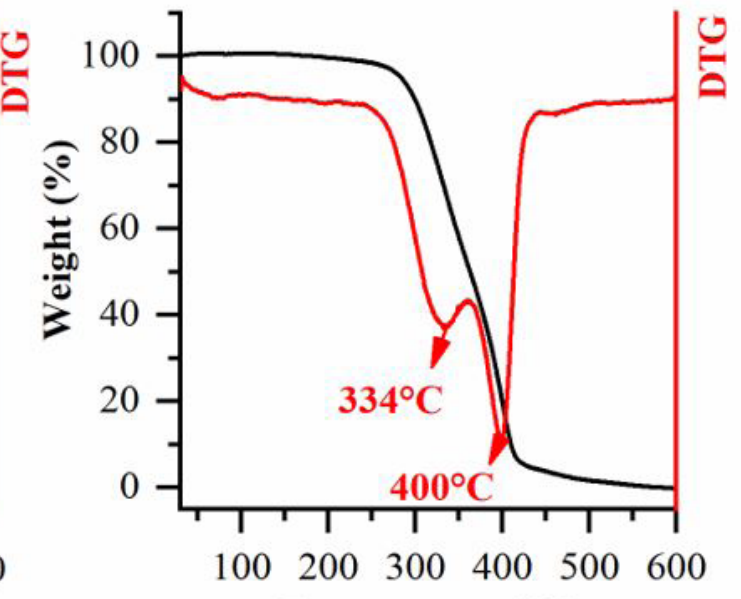

Temperature $\left({ }^{\circ} \mathrm{C}\right)$

(D)

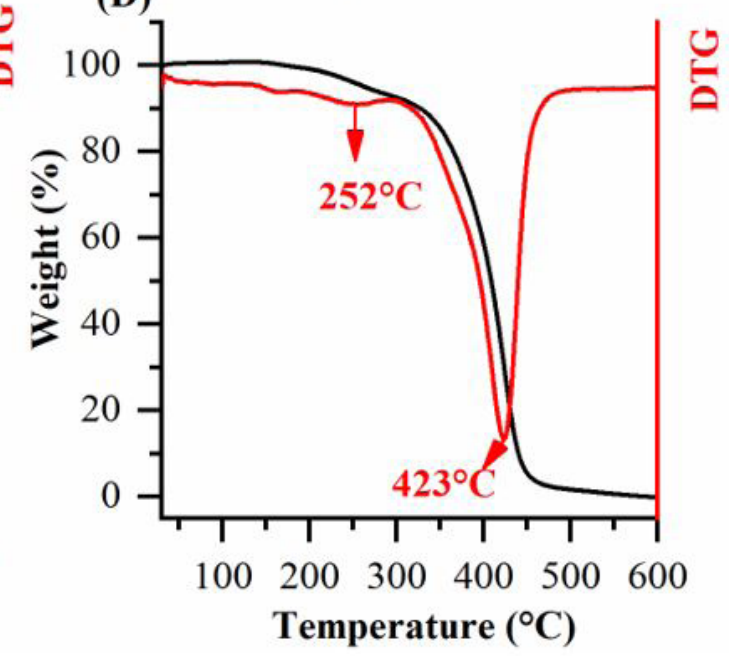

Figure 5. Termogravimetric analysis (A) PCL, (B) PCLT100, (C) PCLT250 and (D) PCLT500.

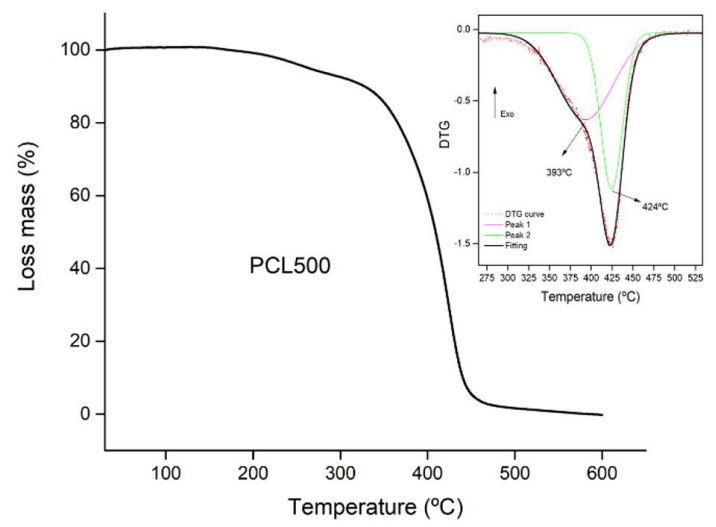

Figure 6. DTG curve for PCLT500 sample analyzed by least squares fit of gaussian functions.

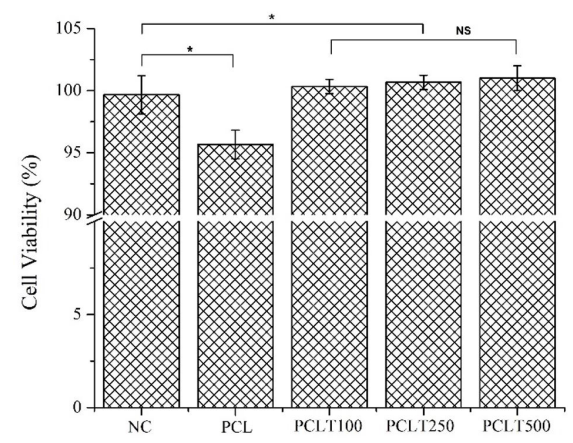

Figure 7. Cell viability assay of Peripheral Blood Monocytes (PBMC) Lymphocytes on PCL, 100, 250 and $500 \mu \mathrm{g} / \mathrm{mL}$ Tucuma-loaded PCL nanofibers after 24 hours $(\mathrm{p} \leq 0.05)$. Values are expressed as mean \pm S.D. of three parallel measurements. (* - significant difference; NS - nonsignificant difference). 
this result is significantly smaller when compared to negative control and to all tucuma-loaded PCL samples ( $\mathrm{p} \leq 0.05)$. On the other hand, there was no significant difference in cell viability with all tucuma-loaded samples and negative control $(\mathrm{p} \leq 0.05)$. The results exhibited that tucuma oil could induce cell proliferation on PCL fiber mats. In agreement with the results obtained on this paper, Ongaratto et al. ${ }^{[50]}$ studied the cellular viability of different tucuma extract concentrations $(5,10,50,100$ e $500 \mu \mathrm{g} / \mathrm{mL})$ on PBMCs. The viability of the cells seeded on the pure PCL fibers mats was significantly lower than that of cells cultured on the control well, this result can be credited to the PCL fibers hydrophobic nature ${ }^{[51]}$. The incorporation of tucuman oil into PCL fiber mats leaded to an improvement on cell viability, which suggests that it possess in its chemical composition molecules such as the $\beta$-carotene ${ }^{[52]}$ that can regulate the expression of genes responsible for cell proliferation and differentiation by controlling ROS production and lipid peroxidation $^{[33-55]}$.

\section{Conclusions}

PCL fibers incorporated with tucuma oil were successfully electrospun and were evaluated with respect to their chemical, physical and morphological properties as well as cytotoxicity. The incorporation of tucuma oil did not affected the PCL chemical structure, which was confirmed by XRD and FTIR. Also, the SEM analysis confirmed the fibrous network of PCL and the addition of tucuma oil into this microstructure. In respect to the morphologic properties, it was noted that the mean diameter of PCL fibers decreased with the addition of tucuma oil. Besides that, the incorporation of tucuma oil into the PCL matrix led to a higher thermal stability compared to pristine PCL. Regarding cytotoxicity, the incorporation of tucuma oil showed enhanced biocompatibility, once it increased the cell viability evaluated by an MTT assay and did not present cytotoxicity against PBMCs. Thus, PCL can be electrospun with tucuma oil to achieve a fibrous biomaterial with increased biocompatibility and interesting physical and morphological properties, without altering the PCL chemical structure.

\section{Acknowledgements}

Universidade Franciscana for providing the main materials and infrastructure required to develop this research. To the Instituto Federal de Educação, Ciência e Tecnologia do Amapá, the Universidade Federal de Pelotas, and the Universidade Federal do Rio Grande do Sul. This study was financed in part by the Coordenação de Aperfeiçoamento de Pessoal de Nível Superior - Brasil (CAPES) and Conselho Nacional de Desenvolvimento Científico e Tecnológico (CNPq).

\section{References}

1. Ambekar, R. S., \& Kandasubramanian, B. (2019). Advancements in nanofibers for wound dressing: A review. European Polymer Journal, 117, 304-336. http://dx.doi.org/10.1016/j. eurpolymj.2019.05.020.

2. Heseltine, P. L., Hosken, J., Agboh, C., Farrar, D., HomerVanniasinkam, S., \& Edirisinghe, M. (2019). Fiber formation from silk fibroin using pressurized gyration. Macromolecular Materials and Engineering, 304(1), 1800577. http://dx.doi. org/10.1002/mame.201800577.

3. Padron, S., Fuentes, A., Caruntu, D., \& Lozano, K. (2013). Experimental study of nanofiber production through forcespinning. Journal of Applied Physics, 113(2), 024318. http://dx.doi. org/10.1063/1.4769886.

4. Hou, T., Li, X., Lu, Y., \& Yang, B. (2017). Highly porous fibers prepared by centrifugal spinning. Materials \& Design, 114, 303-311. http://dx.doi.org/10.1016/j.matdes.2016.11.019.

5. Lee, H., Watanabe, K., Kim, M., Gopiraman, M., Song, K.-H., Lee, J. S., \& Kim, I. S. (2016). Handspinning Enabled Highly Concentrated Carbon Nanotubes with Controlled Orientation in Nanofibers. Scientific Reports, 6(1), 37590. http://dx.doi. org/10.1038/srep37590. PMid:27876892.

6. Cipitria, A., Skelton, A., Dargaville, T. R., Dalton, P. D., \& Hutmacher, D. W. (2011). Design, fabrication and characterization of PCL electrospun scaffolds - A review. Journal of Materials Chemistry, 21(26), 9419-9453. http://dx.doi.org/10.1039/ c0jm04502k.

7. Machado-Paula, M. M., Corat, M. A. F., Lancellotti, M., Mi, G., Marciano, F. R., Vega, M. L., Hidalgo, A. A., Webster, T. J., \& Lobo, A. O. (2020). A comparison between electrospinning and rotary-jet spinning to produce PCL fibers with low bacteria colonization. Materials Science and Engineering C, 111, 110706. http://dx.doi.org/10.1016/j.msec.2020.110706. PMid:32279777.

8. Pedram Rad, Z., Mokhtari, J., \& Abbasi, M. (2018). Fabrication and characterization of PCL/zein/gum arabic electrospun nanocomposite scaffold for skin tissue engineering. Materials Science and Engineering C, 93, 356-366. http://dx.doi. org/10.1016/j.msec.2018.08.010. PMid:30274067.

9. Oliveira, P. S., Rodrigues, L. F., Jr., Volkmer, T. M., Gerra, N. B., \& Santos, L. A. L. (2019). Obtaining bioabsorable scaffolds from PLGA and IR blend with the addition of hydroxyap-atite. Revista Materia, 24(3). http://dx.doi.org/10.1590/s1517707620190003.0705 .

10. Rodríguez-Tobías, H., Morales, G., \& Grande, D. (2019). Comprehensive review on electrospinning techniques as versatile approaches toward antimicrobial biopolymeric composite fibers. Materials Science and Engineering C, 101, 306-322. http:// dx.doi.org/10.1016/j.msec.2019.03.099. PMid:31029324.

11. Koepsell, L., Remund, T., Bao, J., Neufeld, D., Fong, H., \& Deng, Y. (2011). Tissue engineering of annulus fibrosus using electrospun fibrous scaffolds with aligned polycaprolactone fibers. Journal of Biomedical Materials Research. Part A, 99A(4), 564-575. http://dx.doi.org/10.1002/jbm.a.33216. PMid:21936046.

12. Aghajanpoor, M., Hashemi-Najafabadi, S., Baghaban-Eslaminejad, M., Bagheri, F., Mohammad Mousavi, S., \& Azam Sayyahpour, F. (2017). The effect of increasing the pore size of nanofibrous scaffolds on the osteogenic cell culture using a combination of sacrificial agent electrospinning and ultrasonication. Journal of Biomedical Materials Research. Part A, 105(7), 1887-1899. http://dx.doi.org/10.1002/jbm.a.36052. PMid:28256792.

13. Sharma, D., \& Satapathy, B. K. (2019). Performance evaluation of electrospun nanofibrous mats of polylactic acid (PLA)/poly ( $\varepsilon$-caprolactone) (PCL) blends. Materials Today: Proceedings, 19(Pt 2), 188-195. http://dx.doi.org/10.1016/j.matpr.2019.06.698.

14. Tan, H.-L., Kai, D., Pasbakhsh, P., Teow, S.-Y., Lim, Y.-Y., \& Pushpamalar, J. (2020). Electrospun cellulose acetate butyrate/ polyethylene glycol (CAB/PEG) composite nanofibers: a potential scaffold for tissue engineering. Colloids and Surfaces. B, Biointerfaces, 188, 110713. http://dx.doi.org/10.1016/j. colsurfb.2019.110713. PMid:31884080. 
15. Marques, D. R., Volkmer, T. M., \& Santos, L. A. (2015). Natural polymers: tissue engineering scaffolds. In M. Mishra (Ed.), Encyclopedia of biomedical polymers and polymeric biomaterials (pp. 5648-5657). Boca Raton: CRC Press. http:// dx.doi.org/10.1201/9781351237970.

16. Zhang, B., He, J., Shi, M., Liang, Y., \& Guo, B. (2020). Injectable self-healing supramolecular hydrogels with conductivity and photo-thermal antibacterial activity to enhance complete skin regeneration. Chemical Engineering Journal, 400, 125994. http://dx.doi.org/10.1016/j.cej.2020.125994.

17. Liang, Y., He, J., \& Guo, B. (2021). Functional hydrogels as wound dressing to enhance wound healing. ACS Nano, 15(8), 12687-12722. http://dx.doi.org/10.1021/acsnano.1c04206. PMid:34374515.

18. Sartore, L., Inverardi, N., Pandini, S., Bignotti, F., \& Chiellini, F. (2019). PLA/PCL-based foams as scaffolds for tissue engineering applications. Materials Today: Proceedings, 7(Pt 1), 410-417. http://dx.doi.org/10.1016/j.matpr.2018.11.103.

19. Shao, H., Yu, X., Lin, T., Peng, J., Wang, A., Zhang, Z., Zhang, Y., Liu, S., \& Zhao, M. (2020). Effect of PCL concentration on $\mathrm{PCL} / \mathrm{CaSiO} 3$ porous composite scaffolds for bone engineering. Ceramics International, 46(9), 13082-13087. http://dx.doi. org/10.1016/j.ceramint.2020.02.079.

20. Patrício, T., Domingos, M., Gloria, A., \& Bártolo, P. (2013). Characterisation of PCL and PCL/PLA scaffolds for tissue engineering. Procedia CIRP, 5, 110-114. http://dx.doi. org/10.1016/j.procir.2013.01.022.

21. Yao, Q., Cosme, J. G. L., Xu, T., Miszuk, J. M., Picciani, P. H. S., Fong, H., \& Sun, H. (2017). Three dimensional electrospun PCL/PLA blend nanofibrous scaffolds with significantly improved stem cells osteogenic differentiation and cranial bone formation. Biomaterials, 115, 115-127. http://dx.doi. org/10.1016/j.biomaterials.2016.11.018. PMid:27886552.

22. Coverdale, B. D. M., Gough, J. E., Sampson, W. W., \& Hoyland, J. A. (2017). Use of lecithin to control fiber morphology in electrospun poly ( $\varepsilon$-caprolactone) scaffolds for improved tissue engineering applications. Journal of Biomedical Materials Research. Part A, 105(10), 2865-2874. http://dx.doi.org/10.1002/ jbm.a.36139. PMid:28608414.

23. Wan, X., Liu, P., Jin, X., Xin, X., Li, P., Yuan, J., \& Shen, J. (2018). Electrospun PCL/keratin/AuNPs mats with the catalytic generation of nitric oxide for potential of vascular tissue engineering. Journal of Biomedical Materials Research. Part A, 106(12), 3239-3247. http://dx.doi.org/10.1002/jbm.a.36521. PMid:30289598.

24. Yongcong, F., Zhang, T., Liverani, L., Boccaccini, A. R., \& Sun, W. (2019). Novel biomimetic fiber incorporated scaffolds for tissue engineering. Journal of Biomedical Materials Research. Part A, 107(12), 2694-2705. http://dx.doi.org/10.1002/ jbm.a.36773. PMid:31390481.

25. Ratner, B. D., Hoffman, A. S., Schoen, F. J., \& Lemons, J. E. (Eds.). (2013). Biomaterials science an introduction to materials in medicine. San Diego: Elsevier Academic Press. http://dx.doi.org/10.1016/C2009-0-02433-7.

26. Ding, J., Zhang, J., Li, J., Li, D., Xiao, C., Xiao, H., Yang, H., Zhuang, X., \& Chen, X. (2019). Electrospun polymer biomaterials. Progress in Polymer Science, 90, 1-34. http:// dx.doi.org/10.1016/j.progpolymsci.2019.01.002.

27. Ibrahim, H. M., \& Klingner, A. (2020). A review on electrospun polymeric nanofibers: production parameters and potential applications. Polymer Testing, 90, 106647. http://dx.doi. org/10.1016/j.polymertesting.2020.106647.

28. Juncos Bombin, A. D., Dunne, N. J., \& McCarthy, H. O. (2020). Electrospinning of natural polymers for the production of nanofibres for wound healing applications. Materials Science and Engineering C, 114, 110994. http://dx.doi.org/10.1016/j. msec.2020.110994. PMid:32993991.

29. Inai, R., Kotaki, M., \& Ramakrishna, S. (2005). Structure and properties of electrospun PLLA single nanofibres. Nanotechnology, 16(2), 208-213. http://dx.doi.org/10.1088/0957-4484/16/2/005. PMid:21727424.

30. Matos, K. A. N., Lima, D. P., Barbosa, A. P. P., Mercadante, A. Z., \& Chisté, R. C. (2019). Peels of tucumã (Astrocaryum vulgare) and peach palm (Bactris gasipaes) are by-products classified as very high carotenoid sources. Food Chemistry, 272, 216-221. http://dx.doi.org/10.1016/j.foodchem.2018.08.053. PMid:30309535.

31. Baldissera, M. D., Souza, C. F., Grando, T. H., Sagrillo, M. R., da Silva, A. S., Stefani, L. M., \& Monteiro, S. G. (2017). The use of tucumã oil (Astrocaryum vulgare) in alloxan-induced diabetic mice: effects on behavior, oxidant/antioxidant status, and enzymes involved in brain neurotransmission. Molecular and Cellular Biochemistry, 436(1-2), 159-166. http://dx.doi. org/10.1007/s11010-017-3087-9. PMid:28577189.

32. Lalouckova, K., Skrivanova, E., Rondevaldova, J., Frankova, A., Soukup, J., \& Kokoska, L. (2021). In vitro antagonistic inhibitory effects of palm seed crude oils and their main constituent, lauric acid, with oxacillin in Staphylococcus aureus. Scientific Reports, 11(1), 177. http://dx.doi.org/10.1038/ s41598-020-80481-0. PMid:33420288.

33. Costa, B. E. T., Santos, O. V., Corrêa, N. C. F., \& França, L. F. (2016). Comparative study on the quality of oil extracted from two Tucumã varieties using supercritical carbon dioxide. Food Science and Technology (Campinas), 36(2), 322-328. http://dx.doi.org/10.1590/1678-457X.0094.

34. Silva, C. N., Hyacienth, D. C., Ferreira, A. M., Vilhena, J. C., Florentino, A. C., Cruz, R. A., Bereau, D., Robinson, J.-C., Carvalho, J. C., \& Fernandes, C. P. (2015). Development of nanoemulsions with Tucumã (Astrocaryum vulgare) fruits oil. Journal of Nanomedicine Research, 2(2), 00024. http://dx.doi. org/10.15406/jnmr.2015.02.00024.

35. Cordenonsi, L. M., Santer, A., Sponchiado, R. M., Wingert, N. R., Raffin, R. P., \& Schapoval, E. E. S. (2019). Amazonia products in novel lipid nanoparticles for fucoxanthin encapsulation. AAPS PharmSciTech, 21(1), 32. http://dx.doi.org/10.1208/ s12249-019-1601-y. PMid:31863211.

36. Ghosal, K., Manakhov, A., Zajíčková, L., \& Thomas, S. (2017). Structural and surface compatibility study of modified electrospun poly( $\varepsilon$-caprolactone) (PCL) composites for skin tissue engineering. AAPS PharmSciTech, 18(1), 72-81. http:// dx.doi.org/10.1208/s12249-016-0500-8. PMid:26883261.

37. Ghosal, K., Thomas, S., Kalarikkal, N., \& Gnanamani, A. (2014). Collagen coated electrospun polycaprolactone (PCL) with titanium dioxide (TiO2) from an environmentally benign solvent: preliminary physico-chemical studies for skin substitute. Journal of Polymer Research, 21(5), 410. http:// dx.doi.org/10.1007/s10965-014-0410-y.

38. Ghosal, K., Agatemor, C., Špitálsky, Z., Thomas, S., \& Kny, E. (2019). Electrospinning tissue engineering and wound dressing scaffolds from polymer-titanium dioxide nanocomposites. Chemical Engineering Journal, 358, 1262-1278. http://dx.doi. org/10.1016/j.cej.2018.10.117.

39. Ghosal, K., Chandra, A., Praveen, G., Snigdha, S., Roy, S., Agatemor, C., Thomas, S., \& Provaznik, I. (2018). Electrospinning over Solvent Casting: Tuning of Mechanical Properties of Membranes. Scientific Reports, 8(1), 5058. http://dx.doi. org/10.1038/s41598-018-23378-3. PMid:29568048.

40. Ghosal, K., Kováčová, M., Humpolíček, P., Vajd’ák, J., Bodík, M., \& Špitalský, Z. (2021). Antibacterial photodynamic activity of hydrophobic carbon quantum dots and polycaprolactone based nanocomposite processed via both electrospinning and solvent 
casting method. Photodiagnosis and Photodynamic Therapy, 35, 102455. http://dx.doi.org/10.1016/j.pdpdt.2021.102455. PMid:34311091.

41. Wilms, L. C., Hollman, P. C. H., Boots, A. W., \& Kleinjans, J. C. S. (2005). Protection by quercetin and quercetin-rich fruit juice against induction of oxidative DNA damage and formation of BPDE-DNA adducts in human lymphocytes. Mutation Research, 582(1-2), 155-162. http://dx.doi.org/10.1016/j. mrgentox.2005.01.006. PMid:15781220.

42. Leonardi, B., Arauz, L. J., \& Baruque-Ramos, J. (2019). Chemical characterization of amazonian non-polar vegetal extracts (buriti, Tucumã, Brazil Nut, Cupuaçu, and Cocoa) by Infrared Spectroscopy (FTIR) and Gas Chromatography (GC-FID). Infarma - Ciências Farmacêuticas, 31(3), 163-176. http://dx.doi.org/10.14450/2318-9312.v31.e3.a2019.pp163-176.

43. Shimamoto, G. G., Favaro, M. M. A., \& Tubino, M. (2015). Simple methods via Mid-IR or $1 \mathrm{H}$ NMR spectroscopy for the determination of the iodine value of vegetable oils. Journal of the Brazilian Chemical Society, 26(7), 1431-1437. http:// dx.doi.org/10.5935/0103-5053.20150111.

44. Ali, M. E., Nina Naquiah, A. N., Mustafa, S., \& Hamid, S. B. A. (2015). Differentiation of frog fats from vegetable and marine oils by Fourier Transform Infrared Spectroscopy andchemometric analysis. Croatian Journal of Food Science and Technology, 7(1), 1-8. http://dx.doi.org/10.17508/CJFST.2015.7.1.03.

45. Gomez, N. A., Abonia, R., Cadavid, H., \& Vargas, I. H. (2011). Chemical and spectroscopic characterization of a vegetable oil used as dielectric coolant in distribution transformers. Journal of the Brazilian Chemical Society, 22(12), 2292-2303. http:// dx.doi.org/10.1590/S0103-50532011001200009.

46. Felgueiras, H. P., Homem, N. C., Teixeira, M. A., Ribeiro, A. R. M., Antunes, J. C., \& Amorim, M. T. P. (2020). Physical, Thermal, and antibacterial effects of active essential oils with potential for biomedical applications loaded onto cellulose acetate/polycaprolactone wet-spun microfibers. Biomolecules, 10(8), 1129. http://dx.doi.org/10.3390/biom10081129. PMid:32751893.

47. Tampau, A., González-Martínez, C., \& Chiralt, A. (2018). Release kinetics and antimicrobial properties of carvacrol encapsulated in electrospun poly-( $\varepsilon$-caprolactone) nanofibres. Application in starch multilayer films. Food Hydrocolloids, 79, 158-169. http://dx.doi.org/10.1016/j.foodhyd.2017.12.021.

48. Hasanpour Ardekani-Zadeh, A., \& Hosseini, S. F. (2019). Electrospun essential oil-doped chitosan/poly( $\varepsilon$-caprolactone) hybrid nanofibrous mats for antimicrobial food biopackaging exploits. Carbohydrate Polymers, 223, 115108. http://dx.doi. org/10.1016/j.carbpol.2019.115108. PMid:31426968.

49. Kanani, A. G., \& Bahrami, S. H. (2011). Effect of changing solvents on poly( $\varepsilon$-caprolactone) nanofibrous webs morphology. Journal of Nanomaterials, 2011, 724153. http://dx.doi. org $/ 10.1155 / 2011 / 724153$.

50. Ongaratto, F., Bonadiman, B. S. R., Marafon, F., Kosvoski, G. C., Chaves, C. C., Chaves, C. M., Cruz, I. B. M., \& Bagatini, M. D. (2020). Efeito in vitro do extrato de Tucumã (astrocaryum aculeatum) em células mononucleares de sangue periférico. Brazilian Journal of Health Review, 3(3), 5055-5062. http:// dx.doi.org/10.34119/bjhrv3n3-087.

51. Bui, H. T., Chung, O. H., Dela Cruz, J., \& Park, J. S. (2014). Fabrication and characterization of electrospun curcuminloaded polycaprolactone-polyethylene glycol nanofibers for enhanced wound healing. Macromolecular Research, 22(12), 1288-1296. http://dx.doi.org/10.1007/s13233-014-2179-6.

52. Nascimento, K., Copetti, P. M., Fernandes, A., Klein, B., Fogaça, A., Zepka, L. Q., Wagner, R., Ourique, A. F., Sagrillo, M. R., \& da Silva, J. E. P. (2021). Phytochemical analysis and evaluation of the antioxidant and antiproliferative effects of Tucumã oil nanocapsules in breast adenocarcinoma cells (MCF-7). Natural Product Research, 35(12), 2060-2065. http:// dx.doi.org/10.1080/14786419.2019.1648460. PMid:34096432.

53. Sagrillo, M. R., Garcia, L. F., de Souza, O. C., Fo., Duarte, M. M., Ribeiro, E. E., Cadoná, F. C., \& da Cruz, I. B. (2015). Tucumã fruit extracts (Astrocaryum aculeatum Meyer) decrease cytotoxic effects of hydrogen peroxide on human lymphocytes. Food Chemistry, 173, 741-748. http://dx.doi.org/10.1016/j. foodchem.2014.10.067. PMid:25466084.

54. Lomenick, B., Shi, H., Huang, J., \& Chen, C. (2015). Identification and characterization of $\beta$-sitosterol target proteins. Bioorganic \& Medicinal Chemistry Letters, 25(21), 4976-4979. http:// dx.doi.org/10.1016/j.bmcl.2015.03.007. PMid:25804720.

55. Elliott, R. (2005). Mechanisms of genomic and non-genomic actions of carotenoids. Biochimica et Biophysica Acta. 1740(2), 147-154. http://dx.doi.org/10.1016/j.bbadis.2004.12.009. PMid:15949681. 